\title{
ARTICLE OPEN \\ Development of a microfluidic setup to study the corrosion product deposition in accelerated flow regions
}

\author{
John McGrady ${ }^{1}$, Jonathan Duff ${ }^{1}$, Nicholas Stevens ${ }^{1}$, Andrea Cioncolini ${ }^{2}$, Michele Curioni ${ }^{1}$, Andrew Banks ${ }^{3}$ and Fabio Scenini ${ }^{1}$
}

CRUD (Chalk River Unidentified Deposit) forms in the water circuits of nuclear reactors due to corrosion of structural materials and the consequent release of species into the coolant. The deposition of CRUD is known to occur preferentially in regions of the primary circuit of pressurised water reactors (PWRs) where the water flow accelerates. In order to investigate this phenomenon, a micro-fluidic system, recreating plant conditions while using a simplified experimental set-up, was realised. A flow cell, comprising a stainless steel disc with a central micro-orifice, was used to create accelerated flow under representative operating conditions. By monitoring the pressure drop across the cell, the build-up rate (BUR) of CRUD within the micro-orifice was monitored in real time. By this setup, the conditions inducing deposition of CRUD under PWR conditions were emulated and CRUD deposition was induced in the accelerated flow region. Further effects associated with the presence of lithium hydroxide were investigated in real-time.

npj Materials Degradation (2017)1:21; doi:10.1038/s41529-017-0022-1

\section{INTRODUCTION}

CRUD (Chalk River unidentified deposit) is a term that is used to describe corrosion products that are found in the water circuits of nuclear reactors due to the corrosion of structural materials, and were first observed at the Chalk River power plant. ${ }^{1}$ The formation, accumulation and release of these corrosion products from internal structural surfaces can cause issues within the primary circuit of a pressurised water reactor (PWR), such as heat transfer reduction from the primary to secondary circuit, ${ }^{2}$ an increased radiation field around the primary circuit, 3,4 the axial offset anomaly due to deposition on fuel pins, ${ }^{5,6}$ and changing the response of measurement components. ${ }^{7}$ Recent works suggest that electrokinetic effects may be a driving force for CRUD deposition in the low conductivity, high purity coolant conditions found in a PWR..$^{8-12}$ Typical PWR conditions are $295-325^{\circ} \mathrm{C},<0.01$ ppm $\mathrm{O}_{2}, 2-3 \mathrm{ppm} \mathrm{H}, 1-40 \mu \mathrm{S} / \mathrm{cm}, \mathrm{pH} 300^{\circ} \mathrm{C}$ 7-7.4, 0.1-3.5 ppm Li, and $0-2300 \mathrm{ppm} \mathrm{H}_{3} \mathrm{BO}_{3}$. $^{13}$ The deposition of CRUD can also occur in the secondary circuit of the PWR, operating at lower temperatures $\left(T<288^{\circ} \mathrm{C}\right)$ and different water chemistry $(5 \mathrm{ppm}$ of morpholine, $0.3 \mathrm{ppm},<5 \mathrm{ppb}$ of $\mathrm{O}_{2}$, room temperature $\mathrm{pH} \sim 8.5$, conductivity $\sim 2 \mu \mathrm{S} / \mathrm{cm})$. One of the most important examples of CRUD-related issue is the clogging tube support plates. ${ }^{14}$

Electrokinetic effects might arise when a metal comes into contact with a solution; specifically a surface charge forms on the metal, and ions in solution rearrange to maintain charge neutrality within the local region. This generates an 'electric double layer' with a static layer immediately adjacent to the metal, and a diffuse layer where ions can be sheared from the metal by hydrodynamic flow. ${ }^{15}$ The shearing of ions generates a streaming current parallel to the metal surface. In accelerating flow conditions, the increase in streaming current is balanced by a local wall current which promotes Faradaic reactions and corrosion. While the Faradaic current can increase the release of metal ions into the water, the wall current might also further oxidise the $\mathrm{Fe}^{2+}$ ions and, ultimately, induce the formation of magnetite. ${ }^{16}$ Streaming currents become important in low conductivity solutions as the diffuse layer is thick. The magnitude of streaming currents that can be generated depends on a number of factors including solution water chemistry, ${ }^{8}$ flow velocity, ${ }^{17}$ electrochemical potential $^{18}$ and material. ${ }^{19}$

When alloys are exposed to water, oxidation occurs at the surface even for highly corrosion resistant alloys, and metal ions are released into solution. These ions are the precursors to CRUD either in their soluble ionic form or as aggregated oxide/hydroxide particulates. The oxide that forms on stainless steels and nickel based alloys in PWR primary water usually comprises two layers. ${ }^{13}$ The inner layer, only a few nanometres thick, consists of a protective $\mathrm{Cr}$-rich layer (identified as $\mathrm{NiCr}_{2} \mathrm{O}_{4}$ ) and grows by a solid-state diffusion mechanism. ${ }^{20}$ It has been suggested that the inner layer comprises a $\mathrm{Cr}$-oxide sublayer at the metal/oxide interface, which is the main contributor to protection from corrosion. $^{21,22}$ The outer layer is Fe-rich and non-protective and it comprises $\mathrm{Fe}, \mathrm{Ni}$ and $\mathrm{Cr}$ spinel crystals as well as larger $\mathrm{NiFe}_{2} \mathrm{O}_{4}$ crystals. ${ }^{23}$ The outer layer is responsible for the formation of CRUD. It has been also suggested that the layered oxide forms due to the immiscibility of spinel oxides within the chromium rich inner layer. There are forbidden stoichiometries of $\mathrm{Fe} / \mathrm{Ni}$ chromites at temperatures observed within a PWR which leads to the formation of mixed Fe/Ni ferrites that form the outer corrosion layer. ${ }^{24,25}$

From previous reactor experience, the CRUD deposits that form in restrictions such as orifice plates and steam generator tubing tend to form annular ridges downstream of the initial restriction. This observation has been interpreted based on the electrokinetic mechanism described earlier. At the restriction, the hydrodynamic flow of the coolant forms a detachment site from the pipe wall and an attachment site at the restriction; this leads to the formation of a current loop and, consequently, of anodic and cathodic sites at the material surface. CRUD build-up occurs at the

\footnotetext{
${ }^{1}$ School of Materials, University of Manchester, Oxford Road, M13 9PL Manchester, United Kingdom; ${ }^{2}$ School of Mechanical, Aerospace and Civil Engineering, University of Manchester, George Begg Building, M1 3BB Manchester, United Kingdom and ${ }^{3}$ Rolls Royce plc, 65 Buckingham Gate, SW1E 6AT, London, United Kingdom Correspondence: Fabio Scenini (f.scenini@manchester.ac.uk)
} 
anodic site due to the oxidation of dissolved $\mathrm{Fe}^{2+}$ and the precipitation of magnetite, $\mathrm{Fe}_{3} \mathrm{O}_{4}$, which causes the formation of a deposit at the inlet to the restriction. ${ }^{8}$ However, the exact locations of the anodic and cathodic sites at the restriction are still unclear. The deposits consist of two types of species: particulate species which are deposited onto the surface from solution, and crystalline species which grow from the precipitation and oxidation of $\mathrm{Fe}^{2+}$ ions forming crystals. The deposition causes disturbance of the flow downstream of the deposit and the formation of another current loop with local anodic and cathodic sites. A deposit begins to form at the anodic site at the surface causing further disruption of flow downstream, and so the process continues leading to the periodic ridges commonly seen in CRUD deposits in accelerated flow regions. ${ }^{26}$

Previous investigations into the electrokinetic mechanism thought to drive CRUD deposition in regions of accelerated flow utilised flow loops such as the EMILIE system. ${ }^{17,19}$ The loop has been used to recreate PWR operating conditions and investigate CRUD build-up at a restriction by pressure drop measurements across the orifice. In this work, a more simple and cost effective micro-fluidic system has been developed which uses restrictions up to $1 \mathrm{~mm}$ in diameter so that high pressure drops can be attained easily, resulting in measurements that are very sensitive to environmental changes. The developed micro-fluidic system set-up also allows for multiple measurements to be carried out within a single test and is relatively simple to set-up and shut down. Therefore, the turnaround time between subsequent tests is minimal. The use of microfluidic systems for such investigations also allows the electrical behaviour of separate regions of the system to be measured, which has been shown by the current authors to enable investigations of the electrokinetic behaviour of such systems. ${ }^{16}$

The aims of the work presented in this paper are: (i) to develop a small-scale microfluidic system that enables investigation of CRUD deposition under accelerated flow conditions in simulated PWR conditions, (ii) to validate the hydrodynamics of the setup and correlate the pressure drop across a restriction with the microorifice diameter to allow the online measurement of CRUD buildup and (iii) to provide an example of how real time pressure and flow measurements can be used to investigate the effect of water chemistry on CRUD deposition. The addition of pressure drop measurements to complement the electrical monitoring of the microfluidic system already demonstrated will further enhance the usefulness of this approach in understanding the coupling between mechanical and electrokinetic factors in CRUD deposition.

\section{RESULTS}

Development and validation of pressure drop measurements across a micro-orifice

The experiments were conducted in a flow cell test that channelled the water towards a $12 \mathrm{~mm}$ stainless steel disc with a micro-orifice of diameter of either 150,300 or $600 \mu \mathrm{m}$. As water accelerates through the orifice, a pressure drop occurs due to the increase in kinetic energy and decrease in pressure energy of the system. As shown previously, ${ }^{27-29}$ the dimensionless pressure drop $K$ across micro-orifices is a function of the orifice Reynolds number $R e$ as follows:

$K=\frac{2 \Delta P}{\rho V^{2}}=3.137 \operatorname{Re}^{-0.0737} ; \operatorname{Re}=\frac{\rho V d}{\mu}$

where $\rho$ and $\mu$ are the fluid density and viscosity, respectively, $\Delta P$ is the pressure drop across the micro-orifice, $V$ is the average flow velocity through the micro-orifice and $d$ is its diameter. Note that in the experiments presented here, $d$ varies with time due to CRUD build up and consequently also $K$ varies with time. In particular, Eq. (1) is applicable for Reynolds number values in the range of $1000-25,000$ that correspond to turbulent flow within the orifice, which is the flow condition of interest here.

The effect of the fluid viscosity can be neglected in first approximation, and Eq. (1) can consequently be approximated as:

$\Delta P \approx 2.54 \rho \frac{Q^{2}}{d^{4}}$

This links directly the pressure drop across the micro-orifice to the volumetric flow rate $Q$ and orifice diameter. Solving Eq. (2) for the latter yields to Eq. (3):

$$
d_{\text {meas }}=\left(2.54 \rho \frac{Q^{2}}{\Delta P}\right)^{0.25} \text {. }
$$

Where $d_{\text {meas }}$ is the calculated micro-orifice diameter that is obtained from the measured pressure drop and volumetric flow rate. Therefore, the instantaneous radial BUR (BUR meas $)$ can be calculated as half of the derivate of $d_{\text {meas }}$ with time according to Eq. 4:

BUR $_{\text {meas }}=\frac{1}{2} \frac{d d_{\text {meas }}}{d \text { time }}$

Scanning electron microscopy (SEM) examinations were conducted on the front surface of the discs to analyse the morphology of the CRUD and to calculate the average BUR of CRUD within the micro-orifice restriction. This was achieved by acquiring SEM images of the discs after testing to quantify the reduction in diameter of the orifice due to the radial build-up of CRUD. As the CRUD deposition was not perfectly uniform, the orifice area was measured using imaging software and then converted into an equivalent diameter, $d_{\mathrm{SEM}}$ and BUR $\mathrm{R}_{\mathrm{SEM}}$ using equation 4 and 5 where $d_{\text {start }}$ is the diameter at the beginning of the test:

$$
\begin{aligned}
& d_{\text {SEM }}=\sqrt{\frac{4 \times \text { Calculated area }}{\pi}} \\
& \text { BUR }_{S E M}=\frac{d_{\text {start }}-d_{\text {eq }}}{2 \times \text { time }}
\end{aligned}
$$

The pressure drop is related to the orifice geometry and coolant flow rate, and the hydraulic calculations carried out showed a good relationship between the measured pressure drop and the hydrodynamic flow for an orifice diameter of 150, 300 and $600 \mu \mathrm{m}$ as shown in Fig. 1. The change in pressure drop due to increased volumetric flow calculated using Eq. (2) (dotted lines) showed a

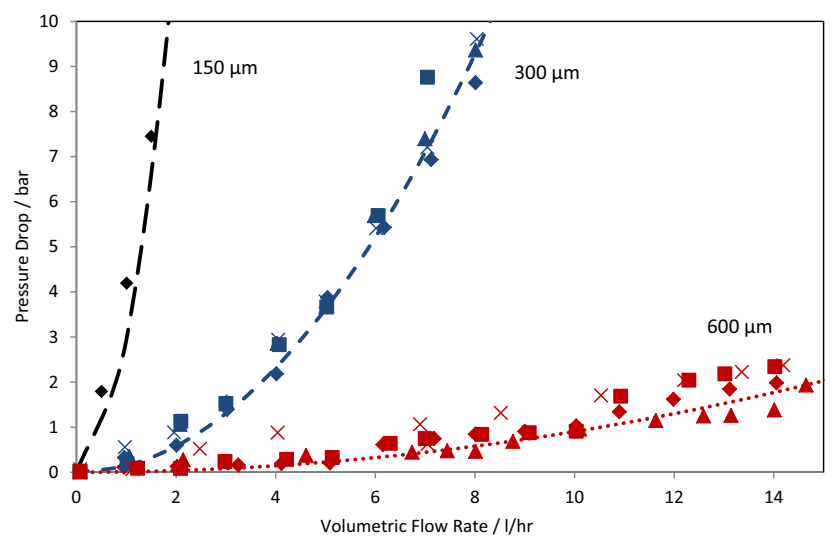

Fig. 1 The predicted pressure drop calculated using Eq. 2 and measured pressure drop across a 150 (black), 300 (blue) and $600 \mu \mathrm{m}$ (red) orifice at $230^{\circ} \mathrm{C}$ and 120 bar inlet pressure as a function of the room temperature volumetric flow rate. The different symbols for the 300 and $600 \mu \mathrm{m}$ orifice refer to individual hydrodynamic tests and the dotted line the predicted hydrodynamic behaviour 

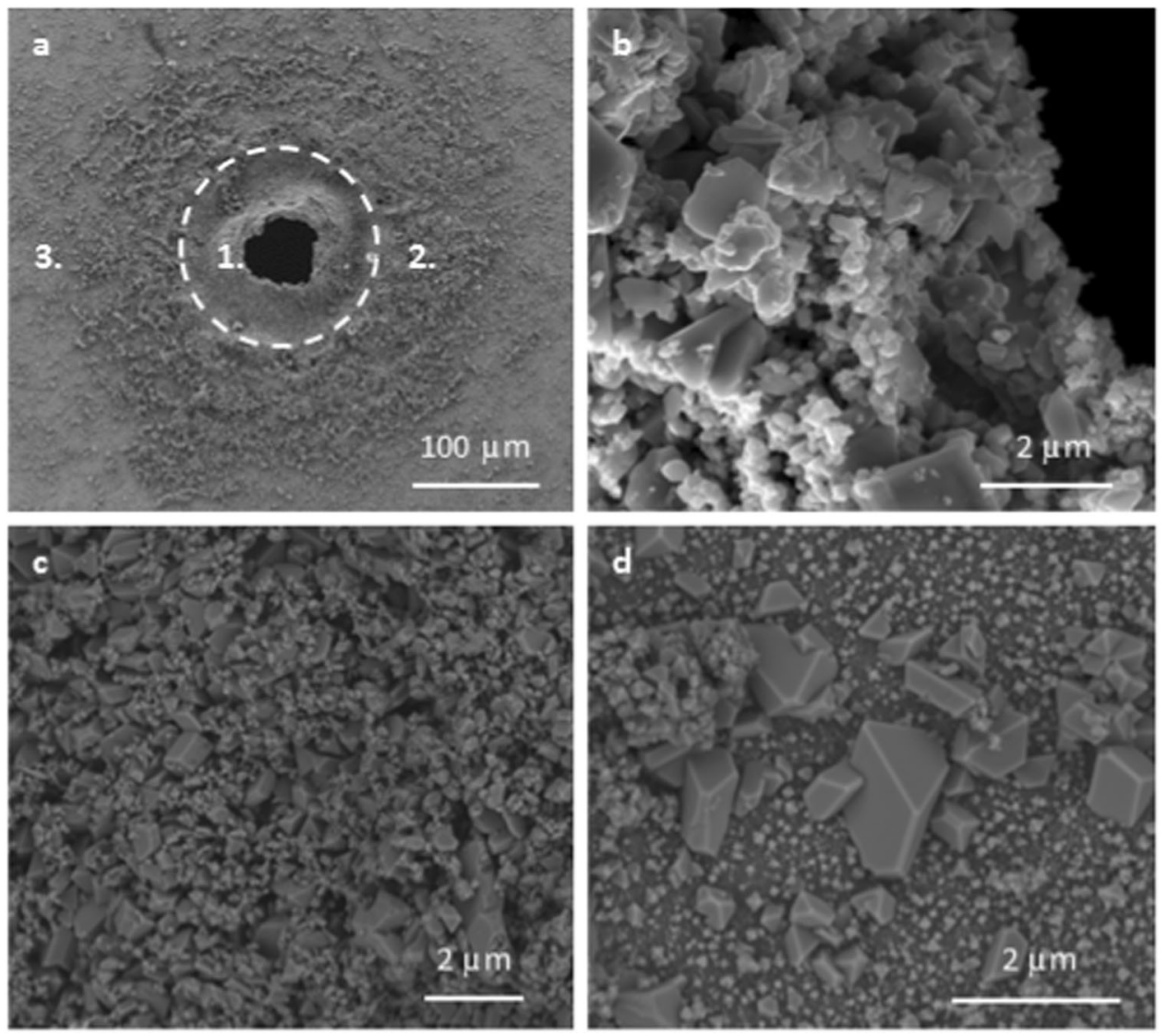

Fig. 2 a SEM image of a 304 stainless steel disc with central micro-orifice of $150 \mu \mathrm{m}$ that was exposed to the flow cell at $230{ }^{\circ} \mathrm{C},<2 \mathrm{ppb} \mathrm{O}_{2}, 2.5$ $\mathrm{ppm} \mathrm{H}_{2}, 66.5 \mathrm{~m} / \mathrm{s}, 0.05 \mu \mathrm{S} / \mathrm{cm}, 27 \mathrm{~h}$. The dashed circle indicate the original hole of the orifice. $\mathbf{b}$ High magnification images of point 1, c point 2 , and $\mathbf{d}$ point 3

good correlation with the experimentally measured pressure drop (data points). Each hydrodynamic flow test was conducted with individual stainless steel discs, and measurements were taken after opening of the flow cell before CRUD build-up could occur.

\section{CRUD characterisation}

The CRUD that formed during the experiments was characterised using Raman spectroscopy (Renishaw RM System 1000 Mk1 with Renishaw RL633 Helium Neon $633 \mathrm{~nm} 20 \mathrm{~mW}$ laser) and SEM (FEI Magellan FEG-SEM). The composition of the oxide was analysed by Raman Spectroscopy to identify the phases present within the deposited oxide. A 304 stainless steel disc with a micro-orifice of $150 \mu \mathrm{m}$ was exposed to the flow cell in order to understand whether CRUD deposition occurs in within the region of acceleration at $230^{\circ} \mathrm{C}$ in high purity $(0.05 \mu \mathrm{S} / \mathrm{cm})$, deoxygenated water $\left(<2 \mathrm{ppb} \mathrm{O}_{2}\right.$ ) and hydrogenated water $\left(2.5 \mathrm{ppm}\right.$ of $\left.\mathrm{H}_{2}\right)$ at an initial velocity of $66.5 \mathrm{~m} / \mathrm{s}$ for $27 \mathrm{~h}$. High-resolution SEM imaging on the post-tested orifice was conducted to analyse the oxide that formed at the orifice in the accelerated flow region (Fig. 2). At the orifice edge (Fig. 2b), crystalline species were observed that were up to $2 \mu \mathrm{m}$ in size, with particulate material with dimensions in the range $100-500 \mathrm{~nm}$ deposited on top. The oxide appeared to have encroached over the orifice boundary and formed a stable awning over the orifice, thus reducing the diameter of the orifice. It is unclear whether this oxide penetrated down into the orifice, or resided solely on the surface of the inlet. Further away from the orifice edge (Fig. 2c), the CRUD contained crystals approximately $2 \mu \mathrm{m}$ in size, and particulates of $100-500 \mathrm{~nm}$ dimensions. Far from the orifice, (Fig. 2d) much less oxide formation occurred. Within this oxide, larger crystals up to $3 \mu \mathrm{m}$ were found and much less particulate material had deposited on top of the crystals. The stainless steel disc is a representative example of a sample that experienced CRUD deposition, and all other discs in the study were similarly analysed, obtaining similar results.

Raman spectroscopy, shown in supplementary materials in Figure $\mathrm{S} 1$, identified magnetite, $\mathrm{Fe}_{3} \mathrm{O}_{4}$, according to the reference peaks $670\left(A_{1 g}\right), 545\left(F_{2 g}(3)\right)$, and $310\left(E_{g}\right) \mathrm{cm}^{-1}$ reported in references. $^{30-33}$ This analysis confirms that the outer oxide deposited on the disc under simulated PWR conditions using the micro-fluidic set-up is CRUD.

Validation of pressure drop analysis technique to measure CRUD BUR

The experiments were conducted at $230{ }^{\circ} \mathrm{C}, \mathrm{O}_{2}<2 \mathrm{ppb}, \mathrm{H}_{2} 2.5$ $\mathrm{ppb}, 0.055 \mu \mathrm{S} / \mathrm{cm}$, imposing a pressure drop and measuring the evolution of flow rate with time. The pressure drop across the micro-orifice was controlled via two back pressure regulators throughout the experiment. One back pressure controlled the upstream pressure of the inlet and diverted any excess fluid into a bypass line (see experimental details in section 4.1). The downstream pressure was controlled via a back pressure regulator that was fitted prior to a flow meter. By monitoring the reduction in flow through the orifice due to CRUD formation, the water flow could be used to calculate $d_{\text {meas }}$ using Eq. 3 . The flow through the 150, 300 and $600 \mu \mathrm{m}$ micro-orifices are shown in Fig. 3a, c, e, and show that the flow decreased throughout the test as build-up occurred within the orifice. The corresponding $d_{\text {meas }}$ for each disc is shown in Fig. 3b, d, f. For the $150 \mu \mathrm{m}$ micro-orifice, high velocity through the orifice occurred due to the narrow orifice restriction, and the velocity decreased from 60 to $50 \mathrm{~m} / \mathrm{s}$ throughout the test 

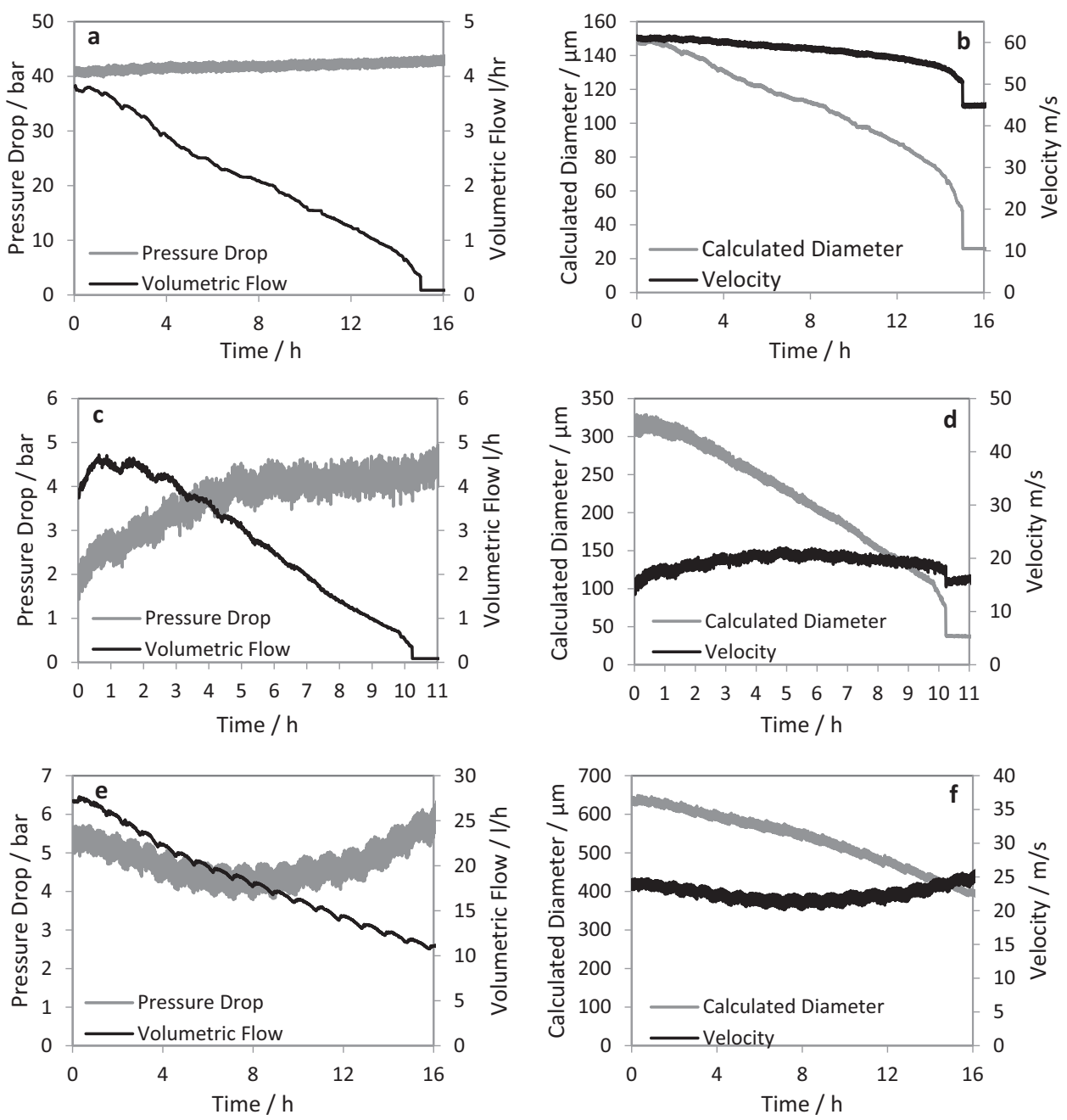

Fig. $3 \mathbf{a}, \mathbf{c}$, e Time evolution of pressure drop and volumetric flow, $\mathbf{b}, \mathbf{d}, \mathbf{f}$ time evolution of velocity and calculated diameter for the tests with a $150 \mu \mathrm{m}(\mathbf{a}, \mathbf{b}), 300 \mu \mathrm{m}(\mathbf{c}, \mathbf{d})$, and a $600 \mu \mathrm{m}$ orifice $(\mathbf{e}, \mathbf{f})$. The tests were conducted at $230{ }^{\circ} \mathrm{C},<2 \mathrm{ppb} \mathrm{O}_{2}, 2.5 \mathrm{ppm} \mathrm{H}_{2}$ and $0.05 \mu \mathrm{S} / \mathrm{cm}$

and eventually dropped to zero once the orifice was fully blocked. The velocity through the $300 \mu \mathrm{m}$ orifice was relatively constant between $15-20 \mathrm{~m} / \mathrm{s}$ until, after about $10 \mathrm{~h}$ the orifice was almost completely clogged. The test conditions were left unchanged with a pressure drop of $\sim 5$ bar. After a total of $16.7 \mathrm{~h}$, the pressure drop was increased to 10 bar which caused the orifice to become unblocked and the flow was reinstated and the measured diameter increased to $198 \mu \mathrm{m}$ (Figure S2). For the $600 \mu \mathrm{m}$ orifice, the water velocity was between 20 and $25 \mathrm{~m} / \mathrm{s}$, with an initial decrease followed by an increase, thus mirroring the pressure drop evolution during the test.

Since the purpose of this work was to validate the online buildup measurement technique, at the end of each build-up test the discs were imaged by SEM in order to calculate the equivalent diameter, $d_{\mathrm{SEM}}$ and $\mathrm{BUR}$ SEM according to equation 5 and 6 . The SEM images of the front face of disc of orifice sizes 150, 300 and $600 \mu \mathrm{m}$ are shown in Fig. $4 a-c$, respectively. The build-up was not symmetrical and this may be due to flow turbulence caused by impurities on the surface of the disc which alter the flow pattern as water accelerates towards the orifice. It must also be noted that the build-up of CRUD was not restricted to the orifice, but also occurred on the surface of the disc adjacent to the orifice. This surface build-up would also have a large effect on the hydrodynamics and on the deposition of CRUD. The orifice diameters for the three orifices calculated from the hydrodynamic data $\left(d_{\text {meas }}\right)$ matched reasonably well the values measured post- test using a SEM $\left(d_{\mathrm{SEM}}\right)$. Specifically, for the $150-\mu \mathrm{m}$ orifice $d_{\text {meas }}=$ $26 \mu \mathrm{m}$ and $d_{\mathrm{SEM}}=0 \mu \mathrm{m}$, for the $300-\mu \mathrm{m}$ orifice $d_{\text {meas }}=198 \mu \mathrm{m}$ and $d_{\mathrm{SEM}}=210 \mu \mathrm{m}$, while for the $600-\mu \mathrm{m}$ orifice $d_{\text {meas }}=383 \mu \mathrm{m}$ and $d_{\mathrm{SEM}}=367 \mu \mathrm{m}$ (see also Supplementary Table S1). Overall the measuring error was between -12 and $+26 \mu \mathrm{m}$ over the range of investigated orifices. The biggest error was obtained for very low flow rates on the blocked $150 \mu \mathrm{m}$ orifice, when the flow meter operates at the bottom of the scale.

The BUR meas can also be calculated from the time evolution of the $d_{\text {meas }}$ (Fig. $3 \mathrm{~b}, \mathrm{~d}, \mathrm{f}$ ); in particular, it is equal to half of the derivative of the calculated diameter with respect to the time, presented in Fig. 5 for all the orifices. Within the first 1-2 $\mathrm{h}$ the BUR increased for all the orifices; thereafter it approached a steady value between 2 and $3 \mu \mathrm{m} / \mathrm{h}$ for the $150 \mu \mathrm{m}$ orifice and between 5 and $8 \mu \mathrm{m} / \mathrm{h}$ for the $300 \mu \mathrm{m}$ orifice. The BUR for the $600 \mu \mathrm{m}$ orifice increased progressively from 10 to $15 \mu \mathrm{m} / \mathrm{h}$ throughout the test. From SEM analysis, the average BUR for the $150 \mu \mathrm{m}$ was $5.0 \mu \mathrm{m} / \mathrm{h}$, for the $300 \mu \mathrm{m}$ was $2.7 \mu \mathrm{m} / \mathrm{h}$ and for the $150 \mu \mathrm{m}$ was $7.1 \mu \mathrm{m}$ (see also Supplementary Table S1). The difference between the BUR of Fig. 5 and those estimated by SEM is due to the fact that the SEM value can only represent an average value for the entire test, whereas the data in Fig. 5 can be considered instantaneous values.

Overall, the $150 \mu \mathrm{m}$ orifice had the lowest BUR, while $300 \mu \mathrm{m}$ the highest BUR. This is due to the fact that build-up of CRUD may attain a dynamic equilibrium between formation and removal of the radial oxide. In fact, the velocity was the highest for the 

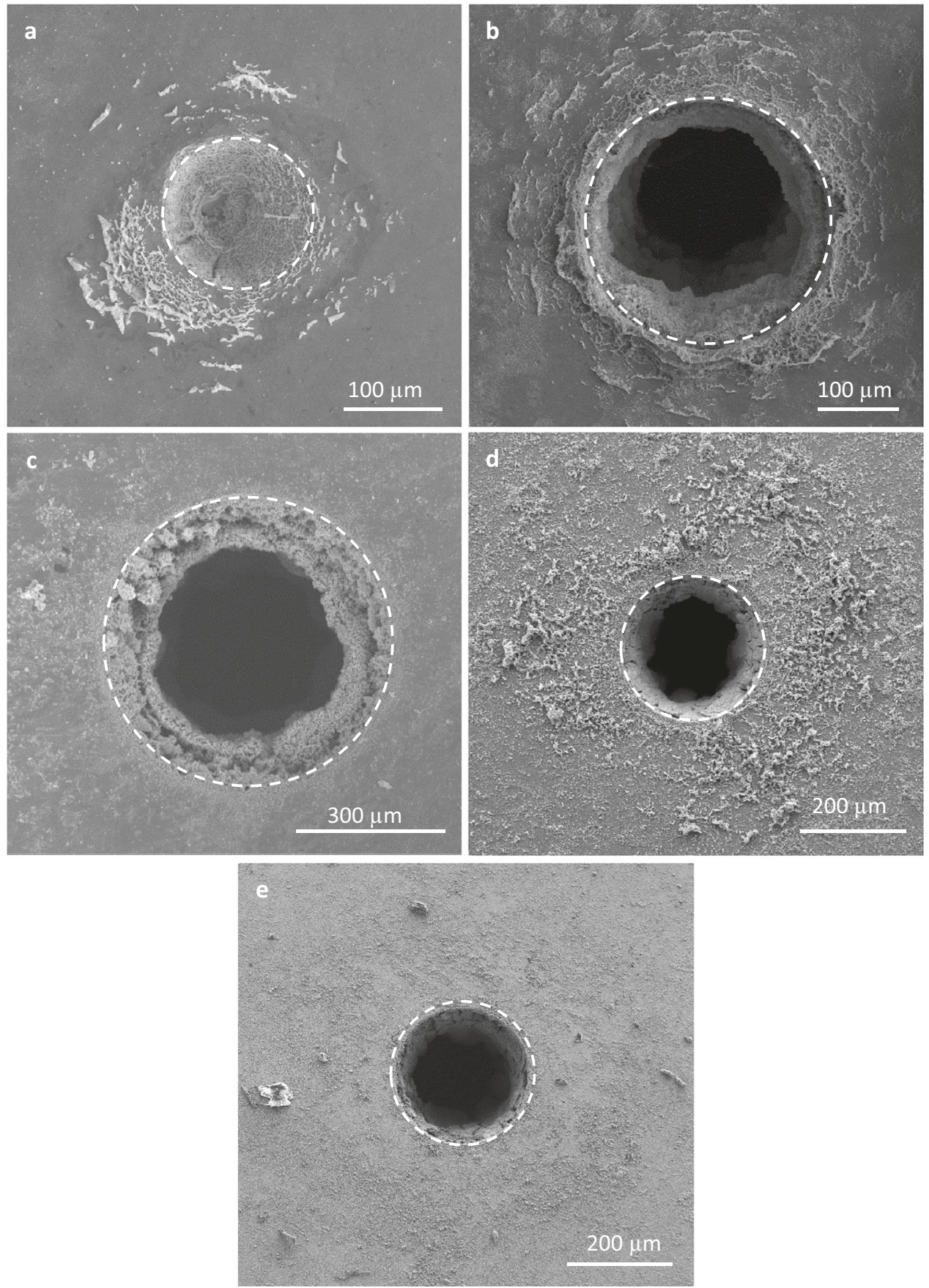

Fig. 4 SEM images of the front face of three stainless steel discs containing a $150 \mu \mathrm{m}, \mathbf{b} 300 \mu \mathrm{m}$ and c $600 \mu \mathrm{m}$ micro-orifice showing preferential CRUD build-up at the orifice restriction after a test at $230{ }^{\circ} \mathrm{C}$ in de-oxygenated $\left(\mathrm{O}_{2}<2 \mathrm{ppb}\right)$, hydrogenated $\left(\mathrm{H}_{2} 2.5 \mathrm{ppb}\right)$ high purity $(0.055 \mu \mathrm{S} / \mathrm{cm})$ water. d The SEM images of a disc with a $300 \mu \mathrm{m}$ orifice tested in high purity water for $22 \mathrm{~h}$ in $200 \mathrm{ppb} \mathrm{H}, 3.8 \mathrm{l} / \mathrm{h}, 18.1 \mathrm{~m} / \mathrm{s}$, and e after re-activation for $22 \mathrm{~h}$ in similar conditions with the addition of $2 \mathrm{ppm}$ of Li. The white dotted line represents the initial circumference of the micro-orifice

$150 \mu \mathrm{m}$ orifice $(\sim 50-60 \mathrm{~m} / \mathrm{s})$ and, consequently, the mechanical oxide removal effects dominated over the electrokinetic effects. Further, the $300 \mu \mathrm{m}$ orifice displayed a higher BUR than $600 \mu \mathrm{m}$ orifice. In this case, the velocity was comparable $(\sim 20 \mathrm{~m} / \mathrm{s})$, but the $300-\mu \mathrm{m}$ orifice was associated with a lower Reynold number (see Eq. 1). Consequently less shear stress and lower mechanical removal rate are expected. Overall, the BURs measurement results suggest that the deposition of CRUD is a complex mechanism dependant on hydrodynamics, mechanical stresses and electrokinetic considerations.
Example of BUR monitoring application-investigation of effect of dissolved $\mathrm{Li}$

As an example of the applicability of the developed micro-fluidic set-up, an investigation into the effect of $\mathrm{LiOH}$ on CRUD build-up was undertaken. Experiments were performed in the absence and presence of lithium ( $2 \mathrm{ppm}$, added as lithium hydroxide). In the absence of lithium, the $\mathrm{pH}$ is close to neutrality and the conductivity is very low, therefore electrokinetic effects should be maximised. On the other hand, with lithium addition, the $\mathrm{pH}$ increases, a condition that is somewhat similar to the later stages 


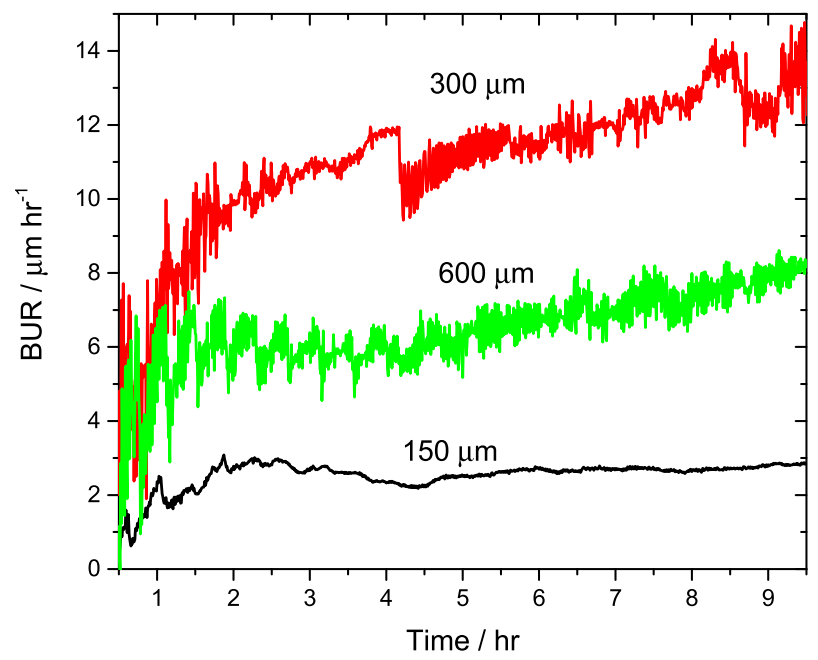

Fig. 5 Time evolution of the radial $B U R_{\text {meas }}$ throughout the test for the discs with $150 \mu \mathrm{m}, 300 \mu \mathrm{m}$ and $600 \mu \mathrm{m}$ orifice. The curves are calculated from the derivative of the curves presented Fig. 3. Adjacent averaging smoothing (1000 points) was applied to the curves of Fig. 3 prior to differentiation. The tests were conducted at $2300^{\circ} \mathrm{C},<2 \mathrm{ppb} \mathrm{O}_{2}, 2.5 \mathrm{ppm} \mathrm{H}_{2}$ and $0.05 \mu \mathrm{S} / \mathrm{cm}$

of the fuel cycle of a PWR when boron (added as boric acid) is reduced. In order to introduce a substantial $\mathrm{pH}$ change, a disc containing a $300 \mu \mathrm{m}$ orifice was exposed to the flow cell in high purity $(0.055 \mu \mathrm{S} / \mathrm{cm})$ deaerated water $\left(0 \mathrm{ppm} \mathrm{H}_{2}\right.$ and $\left.1.5 \mathrm{ppb} \mathrm{O}_{2}\right)$ at a constant flow of $10 \mathrm{l} / \mathrm{h}$. The disc was exposed to the flow cell for $24 \mathrm{~h}$ under non-lithiated conditions before the flow cell was closed for $175 \mathrm{~h}$. Then $2 \mathrm{ppm} \mathrm{LiOH}$ was added to the simulated coolant and the flow cell was reopened for a further $24 \mathrm{~h}$.

The pressure drop across disc 4 during the first $24 \mathrm{~h}$ of exposure to accelerated flow conditions is shown in Fig. 6a where the water contained $0 \mathrm{ppm} \mathrm{Li}$. The pressure drop increased reflecting oxide formation within the orifice. After $18 \mathrm{~h}$, the pressure drop started to fluctuate, suggesting removal of the oxide, most likely due to spallation. After deactivating the flow cell for $175 \mathrm{~h}$, the flow cell was reactivated for $24 \mathrm{~h}$ with deaerated water but with addition of $2 \mathrm{ppm}$ of $\mathrm{Li}$ (added as $\mathrm{LiOH}$ ). The pressure evolution and predicted diameter variation are shown in Fig. 6b. Initially, the pressure drop was the same as before the flow cell deactivation indicating that none of the oxide was lost during deactivation and the CRUD was stable. The changes in pressure drop are reflected in the calculated orifice diameter in unlithiated and lithiated water as shown in Fig. 6a, b respectively.

This observed CRUD deposition reversibility was also confirmed by the SEM examination of an identical disc which was tested in high purity water and subsequently retested in lithiated water. After testing in non lithiated water, the preferential formation of CRUD could be seen on the front surface of the disc up to $350 \mu \mathrm{m}$ from the orifice edge, and within the orifice a build-up of oxide could also be seen (Fig. 4d). The average radial BUR was $1.4 \mu \mathrm{m} / \mathrm{h}$. The disc was then reintroduced to the flow cell to conduct a test under lithiated water chemistry conditions $(2 \mathrm{ppm} \mathrm{LiOH})$ to analyse the effect of lithium on CRUD formation. The CRUD removal was also visible after SEM examination of the disc (Fig. 4e) which shows the inlet to the orifice after exposure to lithiated water, and much of the surface CRUD had been removed.

\section{DISCUSSION}

A micro-orifice flow cell was developed to investigate CRUD buildup under accelerated flow conditions as a small scale representation of a PWR environment. This was achieved by developing a flow cell which was incorporated into an autoclave vessel that could hold a stainless steel disc with a central micro-orifice. Activation of the flow cell caused acceleration of simulated PWR coolant through the micro-orifice, and oxide deposition was observed. The oxide was consistent with CRUD deposits found under PWR conditions as described in the literature ${ }^{26}$ and from plant data; ${ }^{34}$ the morphology of the CRUD comprised both crystalline and particulate material, the majority of which was found adjacent to the orifice edge, and was determined to be $\mathrm{Fe}_{3} \mathrm{O}_{4}$.

The pressure drop technique used to measure the radial BUR of CRUD provided an online monitoring system for deposition by use of a derived equation shown in equation 3 . The real time build-up measurements showed that the BUR of CRUD could be monitored under simulated PWR conditions and provided information on the kinetics of build-up for different micro-orifice diameters. Therefore, this technique has the capability to provide insight into the behaviour of CRUD deposits in regions of accelerated flow under a wide range of water chemistry conditions and hydrodynamic environments.

The accuracy of the pressure drop technique with regards to BUR calculations was investigated by comparison of the diameter from post mortem examination $\left(d_{\mathrm{SEM}}\right)$ with the diameter post $\mathrm{m}$ calculated from hydrodynamic data $\left(d_{\text {meas }}\right)$ and a good agreement was identified for all the three discs tested. This gives confidence about the validity of the measured BUR from hydrodynamic data $\left(B U R_{\text {meas }}\right)$. Furthermore, $B U R_{\text {meas }}$ can be used as a reliable tool to monitor the true evolution of CRUD with time rather relying of the BUR $_{\text {SEM }}$ which is an average value over the entire test. Moreover, thanks to the possibility of inline monitoring, it is also possible to investigate multiple parameters in one single test.

By maintaining constant flow and allowing the pressure drop to increase with radial CRUD build-up, possible spallation of the oxide was observed. The increase in water velocity through the orifice with build-up caused the pressure drop to fluctuate suggesting spallation of the oxide at high flow velocities. This shows that the driving force for electrokinetic deposition and the removal of CRUD are in competition at high flow velocity.

From the initial investigations into CRUD build-up described in this work, the reproducibility of CRUD deposition in accelerated flow regions provided evidence that the experimental set-up described is representative of plant conditions, while being simpler and more efficient than other common experimental setups.

Regarding the effect of lithium on radial build-up, this was investigated by adding $2 \mathrm{ppm} \mathrm{LiOH}$ to the water flowing through an orifice previously exposed to the flow cell which had experienced CRUD deposition. The pressure drop decreased rapidly within the first $2 \mathrm{~h}$ of exposure to lithiated water and then gradually decreased to an equilibrium value over the next 20 h. This observed reversibility of oxide deposition in increasingly alkaline conditions has previously been observed by Brun et al. who showed that the addition of $\mathrm{LiOH}$ at $295^{\circ} \mathrm{C}$ can lower the pressure drop across an orifice. ${ }^{19}$ The immediate removal of the radial oxide suggests that $\mathrm{Li}$ addition may reverse the electrokinetic driving force for deposition, but the fact that the pressure drop does not return to zero suggests that the Li effect limits the formation of oxide rather than completely inhibiting the process. Post-test SEM analysis also indicated the same effect of $\mathrm{Li}$ on surface CRUD, i.e. the amount of CRUD was significantly reduced but not completely removed and the CRUD removal was more significant for the surface oxide than the oxide in the orifice throat.

The partial reversibility of CRUD deposition under lithiated conditions may be due to solubility considerations affecting the equilibrium between deposition and dissolution/re-entrainment of material from the surface of the disc. An increase in $\mathrm{pH}$ from neutral to alkaline conditions affects the solubility of $\mathrm{Fe}$, causing a 
a

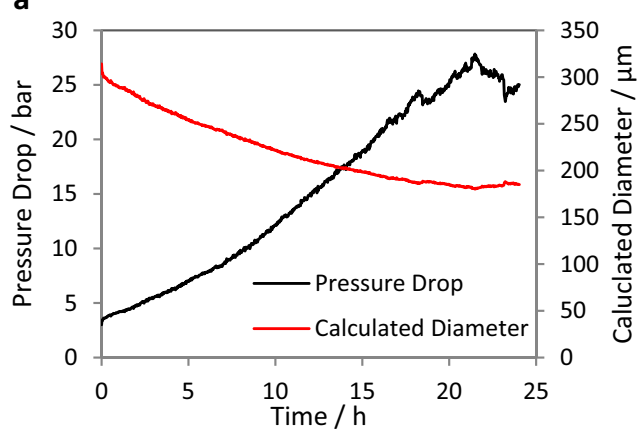

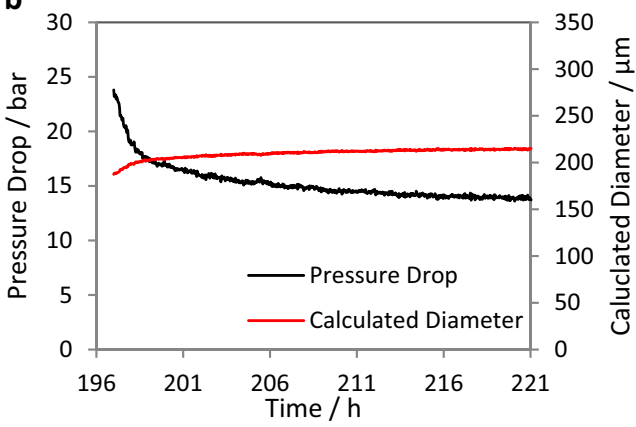

Fig. 6 Pressure drop measurements and calculated orifice diameter evolution for disc 4 . a The flow cell was opened for $24 \mathrm{~h}$ with $0 \mathrm{ppm} \mathrm{Li}$ and

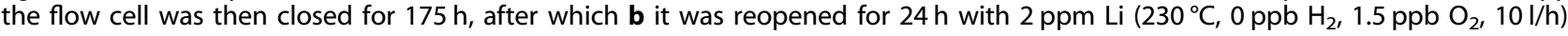

decrease in the amount of dissolved $\mathrm{Fe}(\mathrm{II})$. This reduction in $\mathrm{Fe}(\mathrm{II})$ may shift the equilibrium to favour removal of CRUD, as the mechanical force of the water is unaffected by water chemistry conditions.

The addition of lithium to solution also has the effect of decreasing the magnitude of the zeta potential at the surface due to increased conductivity of the solution. ${ }^{35}$ This would reduce the magnitude of the streaming current and the electrokinetic driving force for deposition. Also, a reduction in the magnitude of the zeta potential would reduce the potential between the surface and bulk solution which is thought to drive electrophoretic deposition of particulates in solution onto surfaces in accelerated flow areas. ${ }^{18,26}$ However, shifting the $\mathrm{pH}$ from $\mathrm{pH}_{235} 5.6$ to 7.2 causes a reduction in the solubility of magnetite, $\mathrm{Fe}_{3} \mathrm{O}_{4}$, which would promote the deposition of species in solution onto the surface of the disc. $^{36}$ This suggests that in the accelerated flow region, solubility effects may be secondary to the electrokinetic effects.

In summary, the work carried out in this paper describes a methodology that allows for investigation into CRUD formation in regions of accelerated flow under simulated PWR conditions using a novel experimental set-up involving microfluidic experiments. An online method of monitoring CRUD build-up rates (BURs) in accelerated flow regions via pressure drop measurements is described, and the following conclusions were made:

- CRUD deposition under accelerated flow conditions in a simulated PWR environment was demonstrated using a microfluidic flow cell and a stainless steel disc with a central microorifice.

- A numerical expression was derived to relate pressure drop, flow and orifice diameter. Hydrodynamic tests showed a good relationship between measured pressure drop and predicted pressure drop, validating the numerical expression relating pressure drop and flow to orifice diameter at $230^{\circ} \mathrm{C}$.

- The radial BUR of CRUD in the accelerated flow conditions of a micro-orifice was monitored online by measuring the pressure drop and flow across the micro-orifice.

- The preferential build-up of surface CRUD in accelerated flow conditions was observed, and post-test analysis of the oxide shows that both crystalline and particulate species are found within the CRUD suggesting more than one mechanism of CRUD formation is present. The CRUD consisted of magnetite, $\mathrm{Fe}_{3} \mathrm{O}_{4}$.

- An example of the application of this methodology was shown with the addition of lithium to simulated PWR coolant. Lithiated solutions removed some of the deposited CRUD from the surface, as observed by post-test SEM analysis and online pressure drop analysis. The effects of lithium on CRUD appears to be complex, depending on electrokinetics, ionic solubilities and the electric double layer at the disc's surface, and require further investigation.

\section{METHODS}

High-temperature autoclave

The autoclave used for this work was a recirculating 13-L vessel made of $316 \mathrm{SS}$ that can operate up to $360^{\circ} \mathrm{C}$ and $200 \mathrm{bar}$, with a flow rate of up to $35 \mathrm{l} / \mathrm{h}$. All the pipework in the autoclave loop was made of $316 \mathrm{~L}$ stainless steel, with two $250 \mathrm{~L}$ and $316 \mathrm{~L}$ stainless steel feed tanks. Water chemistry was analysed with hydrogen and oxygen sensors (Orbisphere 510B00/ T1COP000 and Orbisphere 410/A/P1C00000) as well as a conductivity meter (ABB AX410/50001). Dissolved oxygen concentration measurements were made at the outlet of the reaction vessel prior to the ion exchange resins, and conductivity measurements were taken on the inlet water from the feed tank. The hydrogen content of the water was varied between 0 and $2500 \mathrm{ppb}$ while the oxygen content was $<2 \mathrm{ppb}$, and all tests were conducted at $230^{\circ} \mathrm{C}$. In these experiments, the maximum allowable temperature is dictated by the maximum autoclave operating pressure (200 bar) and by the required pressure drop across the orifice. In order to avoid boiling, the downstream pressure needs to be higher than the vapour pressure at a given temperature, and some margin is also necessary to avoid cavitation. Thus the upstream pressure equals the downstream pressure at a given temperature plus the pressure drop. In order to maintain flow velocities in the required range, preliminary testing with the autoclave available indicated that the temperature of $230^{\circ} \mathrm{C}$ represented a reasonable compromise between similarity to service conditions (in terms of temperature) and sufficiently high flow rates.

The simulated PWR water is stored in feed tanks where the water chemistry can be accurately controlled. The water was pumped via a volumetric pump into the autoclave vessel after being pre-heated to the appropriate temperature. The water then flowed through the main return valve and was cooled and depressurised before being flowed through mixed bed ion exchange resins after which it was reinjected into the feed tank. The flow cell placed within the vessel could be activated by closing the main return valve and opening the flow cell valve. A schematic of the flow loop and the flow cell used in this study are shown in Fig. 7.

Experiments were performed by using two different modes; (a) constant volumetric flow and (b) constant average flow velocity. In both cases, in order to monitor pressure drop across the orifice, individual pressure transducers were placed upstream and downstream of the orifice. For experiments at constant volumetric flow (a), the pressure drop was recorded, whereas for experiments at constant average flow velocity, the pressure drop was intentionally maintained constant by acting on the two backpressure regulators. The advantage of constant volumetric flow experiments (a) is that they allow acquiring the complete hydrodynamic characteristics of the orifices with a limited number of tests (Fig. 1). On the other hand, the constant pressure drop experiments (b) have the advantage that the average flow velocity is constant and, therefore, the data obtained provide direct measurement of BUR at that velocity. If the CRUD deposition mechanism was electokinetic, then fluid velocity would be the primary driving force, thus this mode of testing would be the more suited to isolate directly the effect.

\section{BUR of CRUD on micro-orifices}

CRUD build-up under accelerated flow conditions at typical PWR temperature and pressure was investigated by flowing simulated PWR coolant through a 304 type stainless steel disc with a central micro-orifice. This was achieved by mounting the disc in a flow cell with a series of valves 


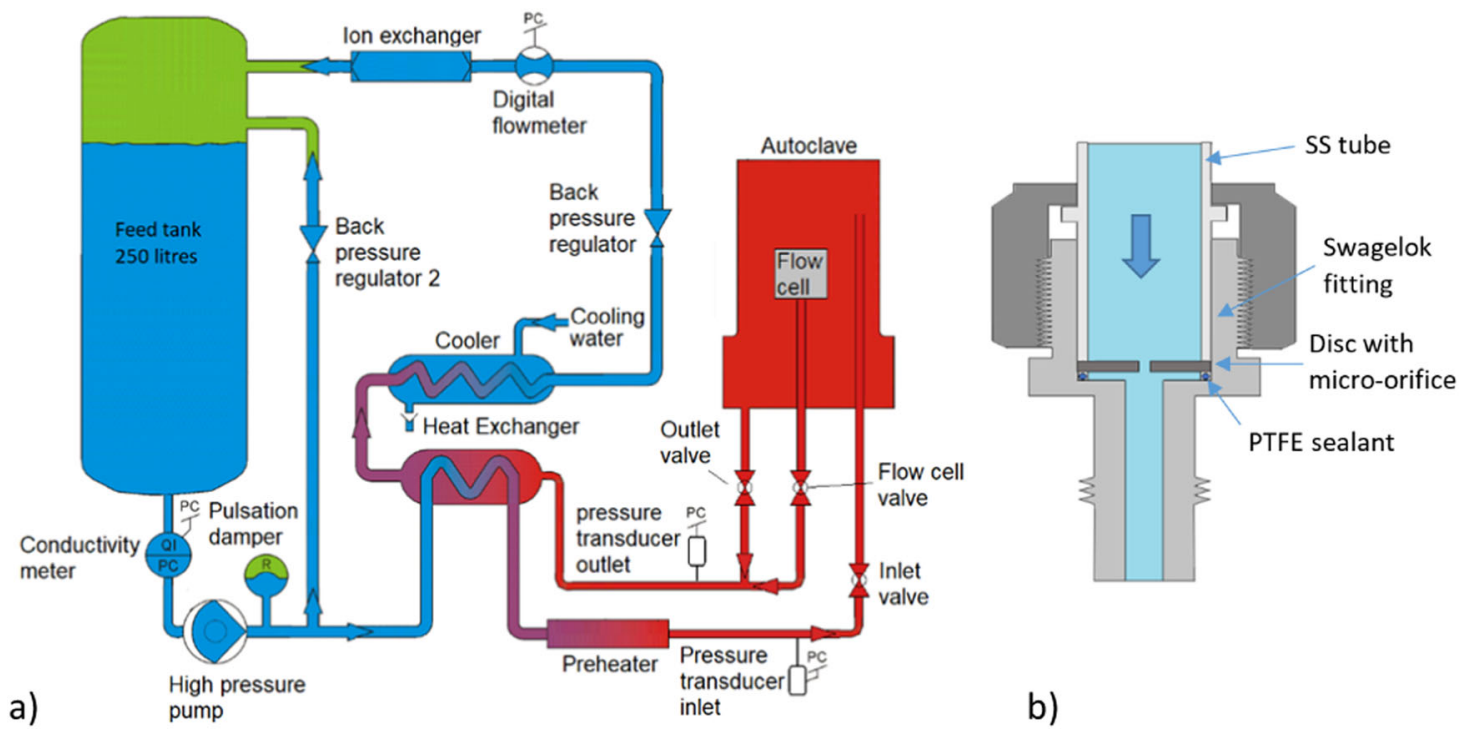

Fig. 7 a Simplified schematic of the recirculating autoclave fitted with the flow cell and $\mathbf{b}$ a schematic of the flow cell. The flow cell could be activated by closing the main outlet valve and opening the flow cell valve

that could activate the coolant flow through the cell with water flowing to an outlet pipe. The discs were $12 \mathrm{~mm}$ in diameter and $1 \mathrm{~mm}$ thick and could be mounted individually or in series to ensure that each disc was under the same flow rate. More details about the flow cell employed can be found in references. ${ }^{27-29,37}$ CRUD deposition was analysed in terms of the change in diameter of the micro-orifice, as well as the pressure drop across the orifice caused by CRUD build-up.

Data availability

All the data discussed are directly presented in the paper and therefore they are automatically accessible.

\section{ACKNOWLEDGEMENTS}

The authors wish to acknowledge support (including an EngD studentship to John McGrady) from the Engineering and Physical Sciences Research Council (Grant Number EP/G037426/1) and Rolls Royce plc. John McGrady 's EngD studentship was $50 \%$ funded via Engineering and Physical Sciences Research Council (Grant Number EP/G037426/1) and 50\% by Rolls Royce plc. The contribution of the other co-authors was supported by Rolls Royce plc.

\section{AUTHOR CONTRIBUTIONS}

J.M.G., J.D. performed the experiments and contributed to experimental design, data analysis and manuscript preparation. F.S., N.S., A.C., M.C. and A.B. contributed to experimental design, data analysis and manuscript preparation.

\section{ADDITIONAL INFORMATION}

Supplementary information accompanies the paper on the npj Materials Degradation website (https://doi.org/10.1038/s41529-017-0022-1).

Competing interests: The authors declare no competing financial interests.

Publisher's note: Springer Nature remains neutral with regard to jurisdictional claims in published maps and institutional affiliations.

\section{REFERENCES}

1. Baes Jr., C. F. \& Handley, T. H. Maritime Reactor Program Annual Progress Report, Water Chemistry Studies 43 (Oak Ridge National Laboratory, Oak Ridge, TN, 1961).

2. Cinosi, N., Haq, I., Bluck, M. \& Walker, S. P. The effective thermal conductivity of crud and heat transfer from crud-coated PWR fuel. Nucl. Eng. Des. 241.3, 792-798 (2011).
3. Tsuey-Lin, T. et al. Identification of chemical composition of CRUD deposition on fuel surface of a boiling water reactor (BWR-6) plant. Energy Procedia 14, 867-872 (2012).

4. Jung, S. H. et al. Investigation on exceptional fuel CRUD samples by using radioactivity ratios of cobalt isotopes. Appl. Radiat. Isot. 81, 307-309 (2013).

5. ul Haq, I., Cinosi, N., Bluck, M., Hewitt, G. \& Walker, S. Modelling heat transfer and dissolved species concentrations within PWR crud. Nucl. Eng. Des. 241.1, 155-162 (2011).

6. Uchida, S., Asakura, Y. \& Suzuki, H. Deposition of boron on fuel rod surface under sub-cooled boiling conditions-An approach toward understanding AOA occurrence. Nucl. Eng. Des. 241.7, 2398-2410 (2011).

7. Lister, D. \& Uchida, S. Determining water chemistry conditions in nuclear reactor coolants. J. Nucl. Sci. Technol. 52.4, 451-466 (2015).

8. Guillodo, M. et al. Formation of deposits in HT water under high velocity conditions: parametric study. In International conference of Water Chemistry of Nuclear Reactor Systems (California-San Fransisco, 2004).

9. Barale, M. et al. Preliminary laboratory tests of investigation on the blockage phenomena observed on TSP of French SGs. In Proc. International Conference on Water Chemistry of Nuclear Reactor Systems, Paper P2-41 (VGB PowerTech, Berlin, 2008).

10. Robertson, J. Corrosion and Deposition Due to Electrokinetic Currents. Report No. TPRD/L/3030, 86 (Central Electricity Generating Board, 1986).

11. Woolsey, I. S., Thomas, D. M., Garbett, K. \& Bignold, G. J. Occurrence and Prevention of Enhanced Oxide Deposition in Boiler Flow Control Orifices (National Power, Leatherhead, UK, 1989).

12. Corredera, G., Alves-Vieira, M. \& De Bouvier, O. Fouling and TSP blockage of steam generators on EDF fleet: identified correlations with secondary water chemistry and planned remedies. In International Conference on Water Chemistry of Nuclear Reactor Systems (VGB PowerTech, Berlin, 2008).

13. Terachi, T. et al. Influence of dissolved hydrogen on structure of oxide film on Alloy 600 formed in primary water of pressurized water reactors. J. Nucl. Sci. Technol. 40.7, 509-516 (2003).

14. Yang, G., Pointeau, V., Tevissen, E. \& Chagnes, A. A review on clogging of recirculating steam generators in pressurized-water reactors. Prog. Nucl. Energy 97, 182-196 (2017).

15. Bard, A. J., Faulkner, L. R., Leddy, J. \& Zoski. C. G. Electrochemical Methods: Fundamentals and Applications, Vol. 2 (Wiley, New York, NY, 1980).

16. Scenini, F., Palumbo, G., Stevens, N., Cook, A. \& Banks, A. Investigation of the role of electrokinetic effects in corrosion deposit formation. Corros. Sci. 87, 71-79 (2014).

17. Barale, M. et al. Secondary side TSP deposit buildup: lab test investigation focused on electrokinetic considerations. In Nuclear Plant Chemistry Conference (Canadian Nuclear Society (CNS), Quebec City, Quebec, Canada, 2010).

18. Guillodo, M. et al. Steam generator fouling assessment by HT zeta potential measurements of bundle materials. In Nuclear Plant Chemistry Conference (VGB PowerTech, 2008). 
19. Brun, C. et al. Investigation on the relation between pressure drops and fluid chemical treatment. In Proc. 9th International Conference on Water Chemistry of Nuclear Reactor Systems (Nuclear Plant Chemistry Conference, Avignon, 2002).

20. Soustelle, C., Foucault, M., Wolski, K., \& Magnin, T. PWSCC of alloy 600: a parametric study of surface film effects. In Ninth International Symposium on Environmental Degradation of Materials in Nuclear Power Systems-Water Reactors (eds Bruemmer, S., Ford, P. \& Was, G.) (Wiley, Hoboken, NJ, USA, 1999).

21. Carrette, F., Guinard, L. \& Pieraggi, B. Kinetics of corrosion products release from nickel-base alloys corroding in primary water conditions a new modeling of release. In Chemistry 2002: International conference on water chemistry in nuclear reactors systems - operation optimisation and new developments (Avignon, France, 2002).

22. Scenini, F. \& Sherry, A. Stress corrosion cracking of sensitized type 304 stainless steel in high-temperature water with anionic impurities contamination. Corrosion 68.12, 1094-1107 (2012).

23. Panter, J. et al. Surface layers on alloys 600 and 690 in PWR primary water possible influence on stress corrosion cracking initiation. In Corrosion (NACE International, 2002).

24. Ziemniak, S. E. \& Castelli, R. A. Immiscibility in the $\mathrm{Fe}_{3} \mathrm{O}_{4}-\mathrm{FeCr}_{2} \mathrm{O}_{4}$ spinel binary. J. Phys. Chem. Solids 64.11, 2081-2091 (2003).

25. Ziemniak, S. E., Gaddipati, A. R. \& Sander, P. C. Immiscibility in the $\mathrm{NiFe}_{2} \mathrm{O}_{4}-\mathrm{NiCr}_{2} \mathrm{O}_{4}$ spinel binary. J. Phys. Chem. Solids 66.6, 1112-1121 (2005).

26. Guillodo, M., Muller, T., Barale, M. \& Foucault, M. Singular deposit formation in PWR due to electrokinetic phenomena-application to SG clogging. In CNS international steam generator conference (Canadian Nuclear Society, Toronto, Ontario, Canada, 2009).

27. Cioncolini, A., Scenini, F. \& Duff, J. Micro-orifice single-phase liquid flow: Pressure drop measurements and prediction. Exp. Therm. Fluid Sci. 65, 33-40 (2015).

28. Cioncolini, A., Scenini, F., Duff, J., Szolcek, M. \& Curioni, M. Choked cavitation in micro-orifices: an experimental study. Exp. Therm. Fluid Sci. 74, 49-57 (2016).

29. Cioncolini, A., Cassineri, S., Duff, J., Curioni, M. \& Scenini, F. Micro-orifice singlephase flow at very high Reynolds number Article reference". Exp. Therm. Fluid Sci. 91, 35-40 (2018).

30. De Faria, D. L. A., Venâncio Silva, S. \& De Oliveira, M. T. Raman microspectroscopy of some iron oxides and oxyhydroxides. J. Raman Spectrosc. 28.11, 873-878 (1997).
31. Hosterman, B. D. Raman spectroscopic study of solid solution spinel oxides. Ph.D thesis, University of Nevade (2011).

32. Dünnwald, J. \& Otto, A. An investigation of phase transitions in rust layers using Raman spectroscopy. Corros. Sci. 29.9, 1167-1176 (1989).

33. Verble, J. L. Temperature-dependent light-scattering studies of the Verwey transition and electronic disorder in magnetite. Phys. Rev. B 9.12, 5236 (1974).

34. Poulson, B. Electrochemical measurements in flowing solutions. Corros. Sci. 23.4, 391-430 (1983).

35. Zhang, Y. H. et al. "Thermal aggregation and gelation of kidney bean (Phaseolus vulgaris L.) protein isolate at $\mathrm{pH}$ 2.0: Influence of ionic strength. Food Hydrocoll. 24.4, 266-274 (2010).

36. Tremaine, PeterR. \& Jacques, C. Le. Blanc "The solubility of magnetite and the hydrolysis and oxidation of $\mathrm{Fe}^{2+}$ in water to $300 \mathrm{C}^{\prime \prime}$. J. Solution Chem. 9.6, 415-442 (1980).

37. McGrady, J., Duff, J. \& Scenini, F. "Investigation into the effect of water chemistry on corrosion product formation in areas of accelerated flow." J. Nucl. Mater. 493, 271-279 (2017).

Open Access This article is licensed under a Creative Commons Attribution 4.0 International License, which permits use, sharing, adaptation, distribution and reproduction in any medium or format, as long as you give appropriate credit to the original author(s) and the source, provide a link to the Creative Commons license, and indicate if changes were made. The images or other third party material in this article are included in the article's Creative Commons license, unless indicated otherwise in a credit line to the material. If material is not included in the article's Creative Commons license and your intended use is not permitted by statutory regulation or exceeds the permitted use, you will need to obtain permission directly from the copyright holder. To view a copy of this license, visit http://creativecommons. org/licenses/by/4.0/.

(c) The Author(s) 2017 